\title{
Processing of fermented fruit juice from acerola (Malpighia glabra L.)
}

\author{
Mai T. N. Tran \\ Institute of Applied Sciences, Ho Chi Minh City University of Technology (HUTECH), Ho Chi Minh City, \\ Vietnam
}

ARTICLE INFO
Research Paper
Received: December 11, 2019
Revised: March 15, 2020
Accepted: April 24, 2020
Keywords
Acerola
Acerola cider
Yeast
Corresponding author
Tran Thi Ngoc Mai
Email: ttn.mai79@hutech.edu.vn

\begin{abstract}
Fruit cider has high nutrition and often preserved cold after processing. The aroma and flavour characteristics of the original material enhance the sensory of the cider. This study was carried on the acerola juice which has the dry matter concentration of $18 \mathrm{oBx}, \mathrm{pH} 4.0$. The fermentation was induced with the yeast content of $0.20 \%$ for 3 days at room temperature. As a result, the obtained product had the dry matter concentration, the alcohol content, the vitamin $\mathrm{C}$ content and $\mathrm{pH}$ of $7.2 \pm 0.8^{\circ} \mathrm{Bx}, 1.4 \% \mathrm{v} / \mathrm{v}, 581.2 \mathrm{mg} \%$ and 3.1 , respectively.
\end{abstract}

Cited as: Tran, M. T. N. (2020). Processing of fermented fruit juice from acerola (Malpighia glabra L.). The Journal of Agriculture and Development 19(2), 99-105. 


\title{
Nghiên cứu chế biến nước giải khát lên men từ quả sơ ri
}

\author{
Trần Thị Ngọc Mai
}

Viện Khoa Học Ứng dụng, Trường Đại Học Công Nghệ TP. HCM (HUTECH), TP. Hồ Chí Minh

THÔNG TIN BÀI BÁO

Bài báo khoa học

Ngày nhận: 11/12/2019

Ngày chỉnh sửa: $15 / 03 / 2020$

Ngày chấp nhận: 24/04/2020

Từ khóa

Nấm men rượu

Nước quả lên men

Sơ ri

Tác giả liên hệ

Trần Thị Ngọc Mai

Email: ttn.mai79@hutech.edu.vn

\section{TÓM TẮT}

Nước trái cây lên men có giá trị dinh dưỡng cao trong đó mùi thơm và hương vị đặc trưng của nguyên liệu làm tăng giá trị cảm quan cho sản phẩm, thường được bảo quản lạnh sau khi chế biến. Nghiên cứu được tiến hành trên dịch quả sơ ri, ở hàm lượng chất khô $18^{\circ} \mathrm{Bx}, \mathrm{pH} 4,0$; tỉ lệ men giống bổ sung $0,20 \%$; lên men trong 3 ngày ở nhiệt độ phòng. Sản phẩm thu được có hàm lượng chất khô $7,2 \pm 0,8^{\circ} \mathrm{Bx}$; hàm lượng cồn 1,4\% v/v; hàm lượng vitamin C 581,2 mg\%; pH 3,1.

\section{1. Đặt Vấn Đề}

Nước giải khát lên men là sản phẩm của quá trình lên men rượu chưa kết thúc từ nguyên liệu trái cây. Đây được xem là loại nước uống tự nhiên có nồng độ cồn thấp, không qua chưng cất, chứa nhiều chất dinh dưỡng, có lợi cho sức khỏe. Thành phần hóa học cơ bản của sản phẩm này gồm: hàm lượng chất kho hòa tan khoảng 5 - $8 \%$ khối lượng; acid tổng từ $0,6-2 \%$ thể tích và nồng độ rượu là 0,5 - 1,5\% thể tích (Bui, 2005; Nguyen \& Nguyen, 2007); đồng thời sản phẩm này còn chứa khá nhiều các hợp chất được sinh ra từ quá trình lên men rượu như các acid hữu cơ, các ester thơm; đặc biệt là các thành phần đặc trưng của nguyên liệu trái cây được sử dụng trong lên men. Trong nước giải khát lên men, các quá trình sinh hóa vẫn tiếp tục dù bảo quản ở nhiệt độ thấp. Do đó, sau lên men có thể loại bớt tế bào nấm men rồi thanh trùng để tăng thời gian bảo quản (Mathew \& ctv., 2017; Saranraj \& ctv., 2017; Souza \& ctv., 2017).
Quả sơ ri (Malpighia glabra L.) thuộc họ Malpighiaceae. Sơ ri có thể trồng ở các vùng nhiệt đới và cận nhiệt đới. Trên thế giới, sơ ri trồng nhiều ở các vùng Bắc Mỹ, Trung Mỹ và Nam Mỹ (Simopoulos \& Gopalan, 2003). Ở Việt Nam, sơ ri trồng phổ biến ở Nam Bộ, đặc biệt là Tiền Giang với diện tích trồng khoảng 950 ha, sản lượng trung bình 18.000 tấn/năm. Thành phần hóa học của quả tươi bao gồm: nước 87,5 - 92,3\%; lipid $0,45-0,47 \%$; protein $0,9-1,2 \%$; đường khử 3,3 $4,4 \%$; đường tổng $4,3 \pm 4,4 \%$; cellulose $0,5-1,2 \%$; tro $0,4-0,6 \%$; K $146 \mathrm{mg} \%$; vitamin C $600-1200$ mg\%; pH 3,4 - 3,7; hàm lượng chất khô hoà tan 7,7 - 9,2\% (Vendramini \& Trugo, 2000; Simopoulos \& Gopalan, 2003; Oliveira \& ctv., 2010).

Sơ ri chín có vỏ mỏng, khó vận chuyển và có thời hạn sử dụng ngắn $2-3$ ngày sau khi hái (Righetto \& ctv., 2005), cùng với sản lượng lớn và thành phần dinh dưỡng tốt cho sức khoẻ, thành phần kháng oxy hoá cao (đặc biệt là vitamin $\mathrm{C}$ ). Trong nghiên cứu này, chúng tôi chế biến nước giải khát lên men từ loại quả này nhằm giải quyết 


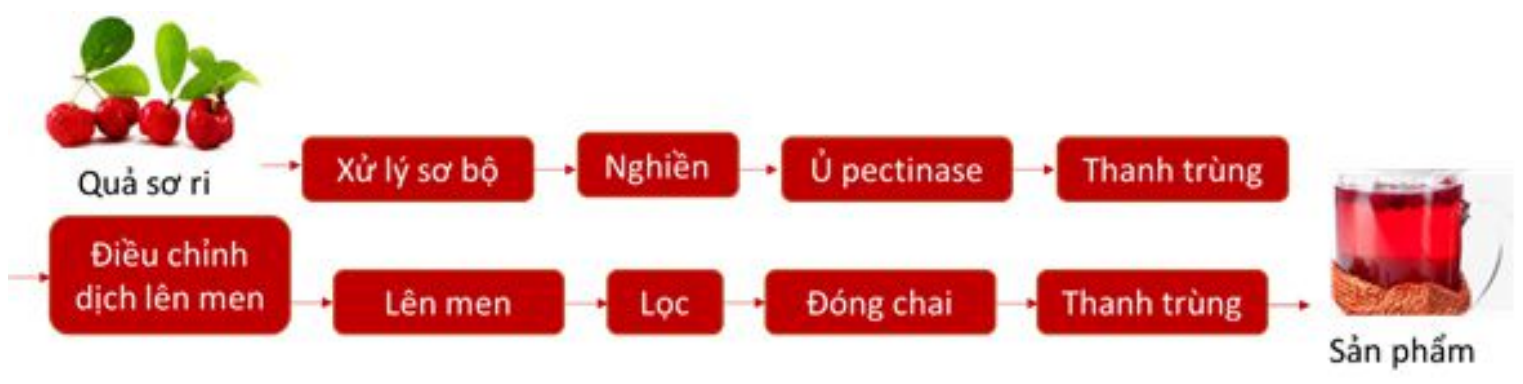

Hình 1. Qui trình chế biến nước sơ ri lên men.

vấn đề về nguồn nguyên liệu dư thừa sau thu hoạch, đồng thời tạo ra một dòng sản phẩn đồ uống có giá trị chức năng kháng oxy hoá, tăng cường miễn dịch, cải thiện sức khoẻ tim mạch.

\section{Vật Liệu và Phương Pháp Nghiên Cứu}

\subsection{Vật liệu}

Quả sơ ri mua tại các vườn ở Gò Công tỉnh Tiền Giang, đạt tiêu chuẩn: quả không bị hư thối, sâu bệnh; màu hồng đến đỏ. Đường saccharose (công ty đường Biên Hoà, đạt TCVN 6958:2001); chất điều chỉnh $\mathrm{pH} \quad \mathrm{Na}_{2} \mathrm{CO}_{3}$ đạt $\mathrm{QCVN}$ 43:2010/BYT; enzyme pectinase (Pectinex Ultra Clear, Novozymes) dạng dung dịch, màu nâu, pH hoạt động 4 - 9, nhiệt độ hoạt động 40 $50^{\circ} \mathrm{C}$, hoạt tính $7900 \mathrm{PGNU} / \mathrm{mL}$; nấm men Saccharomyces cerevisiae (Thermosacc ${ }^{\circledR}$ Dry, Lallemand Biofuels \& Distilled Spirits) dạng nấm men khô, nhiệt độ hoạt động $34-40^{\circ} \mathrm{C}$, pH hoạt động $3,5-6,0 ;$ mật độ tế bào sống trung bình $2 \times 10^{10}$ tế bào/g.

\subsection{Qui trình chế biến}

Qui trình chế biến nước sơ ri lên men thể hiện ở Hình 1. Mỗi thí nghiệm được tiến hành với 500 g quả sơ ri. Tất cả các thí nghiệm được lập lại 3 lần. Quá trình xử lý sơ bộ bao gồm quá trình lựa chọn quả đạt tiêu chuẩn, sau đó rửa sạch. Xử lý dịch quả sau nghiền với enzyme pectinase ở các hàm lượng khác nhau 0,05; 0,10;0,15;0,20\% được tiến hành ở $\mathrm{pH}$ dịch quả, nhiệt độ $45^{\circ} \mathrm{C}$, thời gian 2 giờ; sau khi chọn hàm lượng thích hợp sẽ tiến hành khảo sát thời gian xử lý pectinase $1,2,3$, 4 giờ. Quá trình điều chỉnh dịch lên men được tiến hành điều chỉnh hàm lượng chất khô 15,18 , $21,24^{\circ} \mathrm{Bx}$ bằng đường saccharose, $\mathrm{pH}$ bằng dung dịch $\mathrm{Na}_{2} \mathrm{CO}_{3}$ về $\mathrm{pH} 3,5 ; 4,0 ; 4,5 ; 5,0 ; 5,5$; tỉ lệ men giống 0,$10 ; 0,15 ; 0,20 ; 0,25 \%$ w/w và các chỉ tiêu này được khảo sát theo thời gian lên men từ 1 - 4 ngày ở nhiệt độ phòng (khoảng $25^{\circ} \mathrm{C}$ ).

\subsection{Phương pháp nghiên cứu}

\subsubsection{Phương pháp hoá lý}

Xác định tổng chất khô hoà tan đo bằng Khúc xạ kế (Atago Master-T 0 - 32\% Atc Brix Refractometer, USA), hàm lượng được biểu thị dưới dạng ${ }^{\circ} \mathrm{Bx}$.

Xác định đường khử bằng phương pháp DNS.

Xác định hàm lượng acid tổng theo TCVN 12086:2017.

Xác định độ $\mathrm{pH}$ bằng máy đo $\mathrm{pH}$ (Basic $\mathrm{pH}$ Meter, USA).

Xác định hàm hàm lượng cồn bằng bộ chưng cất và Khúc xạ kế đo độ cồn (PCE-ALK, Anh) thang đo $0-80 \%$.

Xác định hàm lượng vitamin $\mathrm{C}$ bằng phương pháp chuẩn độ với iode theo TCVN 11168:2015.

\subsection{2. Đánh giá cảm quan}

Đánh giá mức độ ưa thích giữa các mẫu nghiên cứu bằng Phép thử so hàng thị hiếu (Phép thử ưu tiên cặp đôi), so sánh sự khác biệt về mức độ ưa thích giữa 2 mẫu thử về màu, mùi và vị ở mức ý nghĩa $5 \%$. Số lượng người thử là 60 , kết quả thử được so với Bảng tra so sánh cặp đôi hai phía.

\subsubsection{Phương pháp xử lý số liệu}

Xử lý số liệu bằng phần mềm Statgraphics Centurion XV. Tất cả số liệu được biểu diễn dưới dạng Trung bình $\pm \mathrm{SD}$, các chênh lệch khác biệt thể hiện bằng $\mathrm{a}, \mathrm{b}, \mathrm{c}, \mathrm{d}$ ở mức ý nghĩa $P<0,05$. 

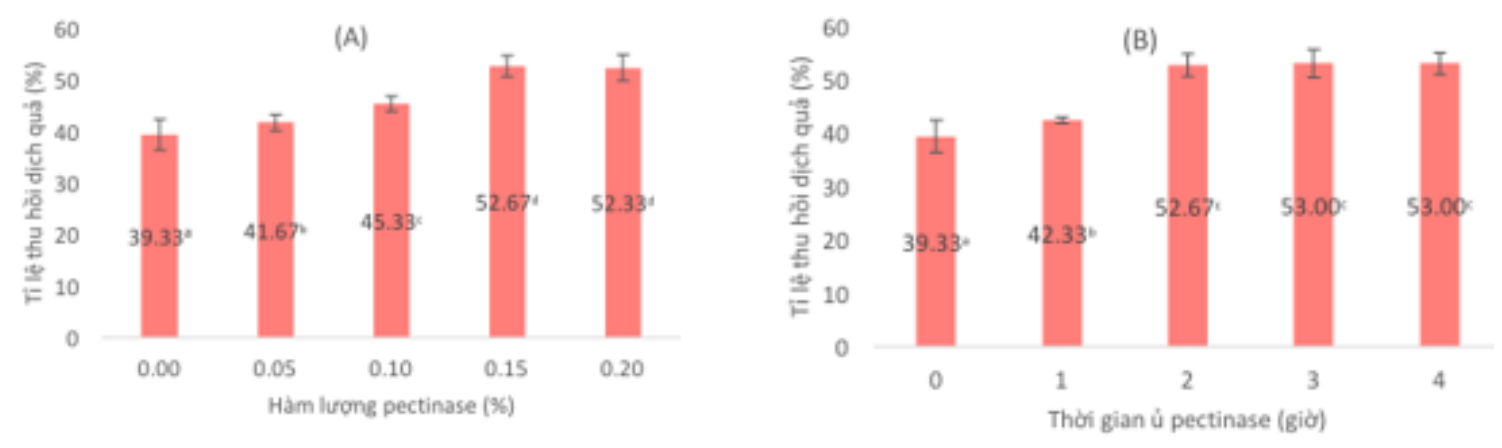

Hình 2. Ảnh hưởng của hàm lượng pectinase $(\mathrm{A})$ và thời gian ủ pectinase (B) đến tỉ lệ thu hồi dịch quả.
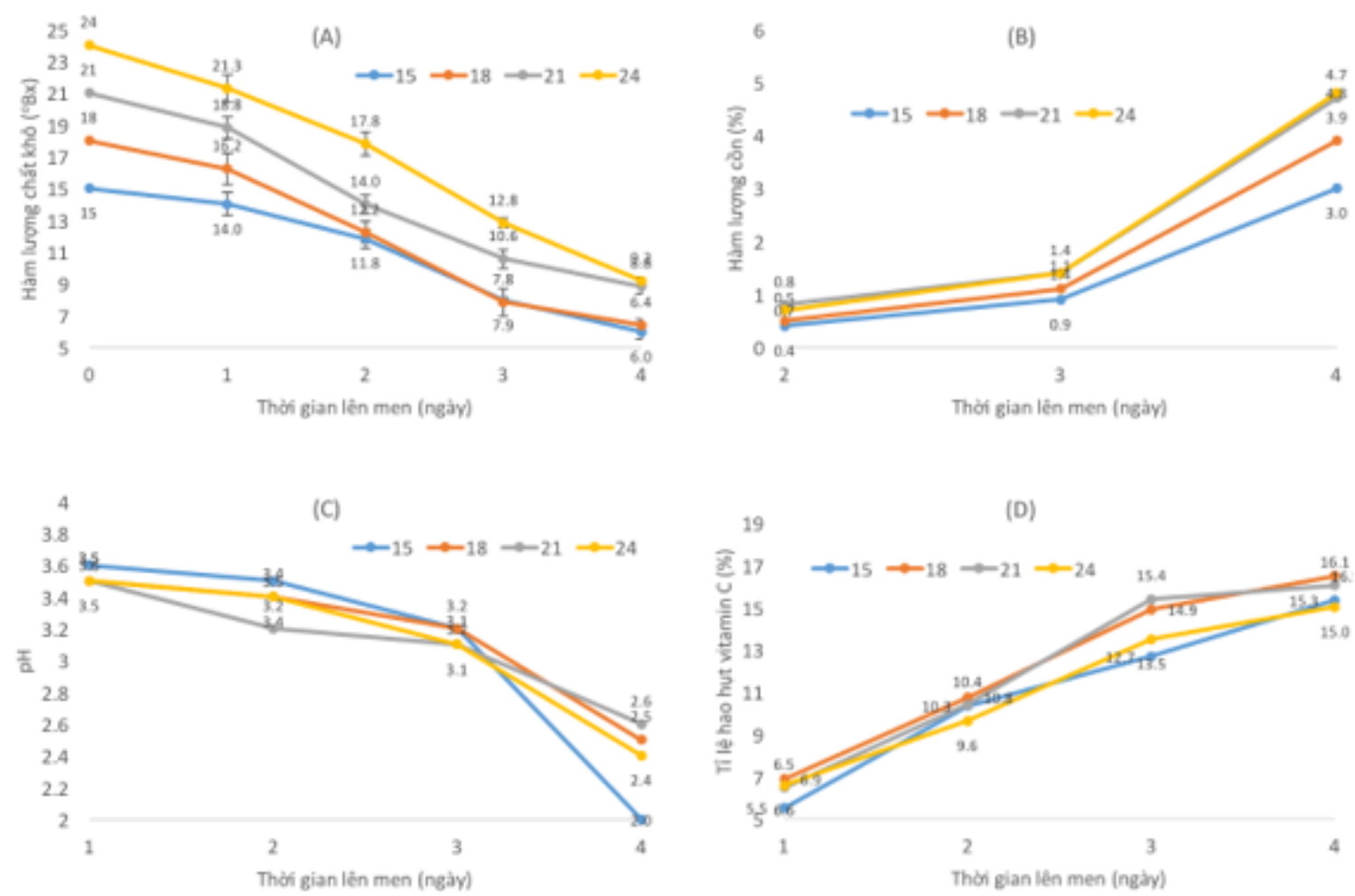

Hình 3. Ảnh hưởng của hàm lượng chất khô ban đầu lên sự thay đổi hàm lượng chất khô $(\mathrm{A})$, hàm lượng cồn $(\mathrm{B}), \mathrm{pH}(\mathrm{C})$ và tỉ lệ hao hụt hàm lượng vitamin $\mathrm{C}(\mathrm{D})$ theo thời gian lên men.

\section{Kết Quả và Thảo Luận}

Thành phần hoá học của quả sơ ri sử dụng trong nghiên cứu có hàm lượng nước $88 \pm 1,8 \%$; hàm lượng chất khô hoà tan $8,4 \pm 0,6^{\circ} \mathrm{Bx} ; \mathrm{pH} 3,2$ $\pm 0,3$; hàm lượng đường khử $3,14 \pm 1,15 \%$; acid tổng $0,78 \pm 0,11 \%$; hàm lượng vitamin $\mathrm{C} 678,57$ $\pm 1,32 \mathrm{mg} \%$.

\subsection{Kết quả khảo sát quá trình xử lý enzyme pectinase}

Enzyme pectinase thu từ hai loại nấm mốc $A s$ pergillus niger và Aspergillus aculeatus có hoạt 

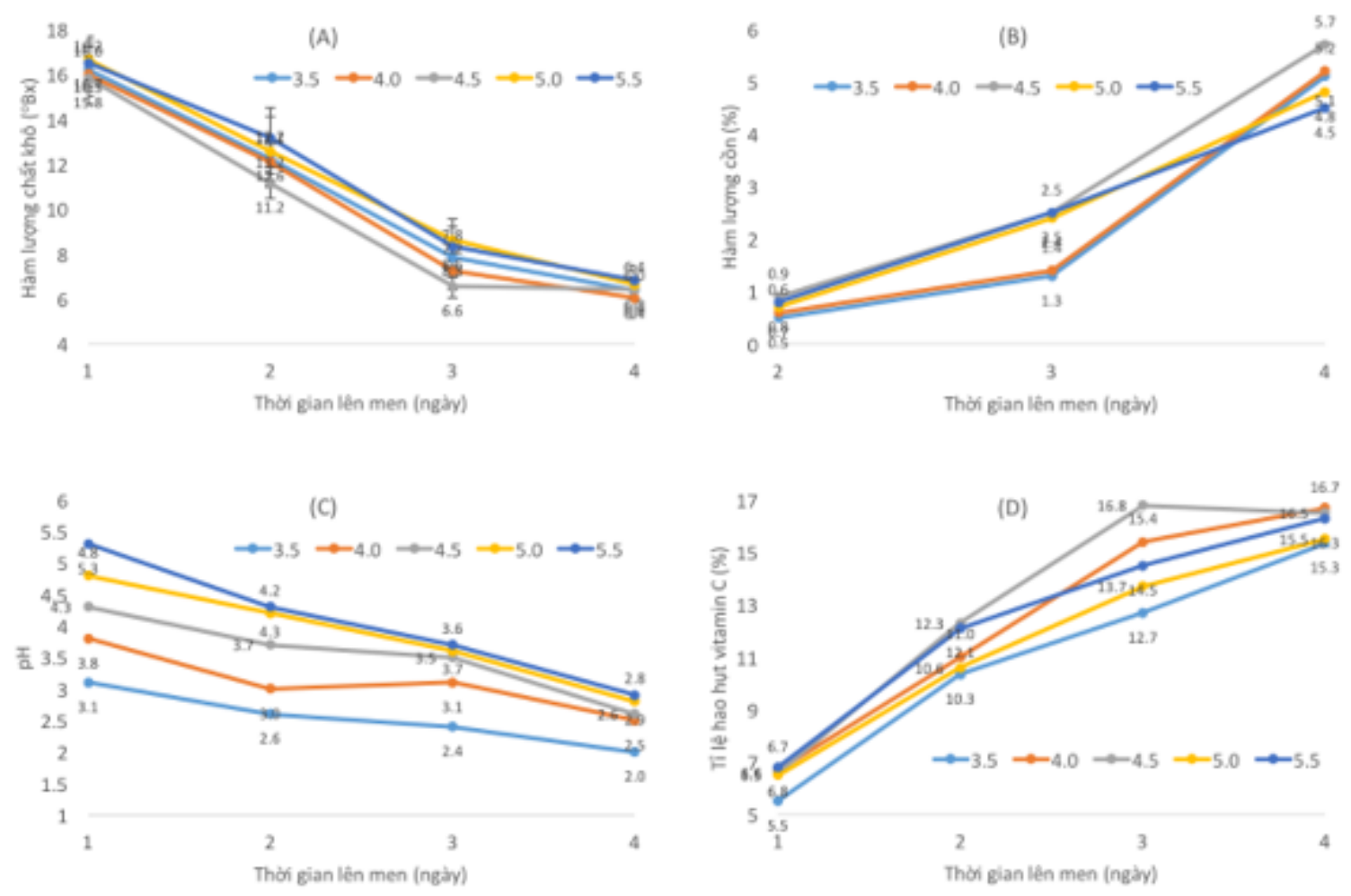

Hình 4. Ảnh hưởng của $\mathrm{pH}$ ban đầu lên sự thay đổi hàm lượng chất khô $(\mathrm{A})$, hàm lượng cồn $(\mathrm{B}), \mathrm{pH}(\mathrm{C})$ và tỉ lệ hao hụt hàm lượng vitamin $\mathrm{C}(\mathrm{D})$ theo thời gian lên men.

tính của enzyme polygalacturonase thủy phân liên kết $(1,4)$-alpha-D-galactosiduronic trong pectate và các galacturonans khác, làm phá vỡ cấu trúc thành tế bào, giảm độ nhớt dịch quả, kết quả là làm tăng hiệu suất thu hồi dịch và làm trong dịch quả.

Hình 2 cho thấy hàm lượng enzyme và thời gian ủ có ảnh hưởng đến tỉ lệ thu hồi dịch quả, so với dịch quả không xử lý enzyme thì tỉ lệ thu hồi dịch có sự khác biệt ở mức ý nghĩa $P<0,05$ điều này cho thấy hiệu quả của việc xử lý enzyme làm tăng tỉ lệ thu hồi dịch quả. Ở các hàm lượng $0,15 \%, 0,20 \%$ cũng như ở thời gian ủ 2 giờ, 3 giờ, 4 giờ không có khác biệt ở mức ý nghĩa $P<0,05$; do đó, nhằm tiết kiệm chi phí và thời gian, hàm lượng phù hợp được chọn để xử lý dịch quả sơ ri là $0,15 \%$ thời gian xử lý là 2 giờ.

\subsection{Kết quả khảo sát quá trình lên men}

Việc điều chỉnh dịch lên men để thu được hàm lượng chất khô, $\mathrm{pH}$, tỉ lệ men giống và thời gian lên men phù hợp với tác nhân Saccharomyces cereviciae là cần thiết cho quá trình lên men diễn ra mạnh mẽ thu được sản phẩm đồ uống đạt tiêu chuẩn hoá lý, vi sinh, đồng thời chất lượng cảm quan sản phẩm cũng phải được đảm bảo.

\subsection{1. Ảnh hưởng của hàm lượng chất khô}

Hàm lượng chất khô trong đó chủ yếu là đường, là thành phần cơ chất cơ bản cho nấm men chuyển hoá. Ở các hàm lượng chất khô khác nhau thì sản phẩm của quá trình chuyển hoá thu được cũng sẽ khác nhau thể hiện qua Hình 3.

Từ biểu đồ các Hình 3 cho thấy sự thay đổi theo thời gian lên men của hàm lượng chất khô, hàm lượng cồn, $\mathrm{pH}$ và tỉ lệ tổn thất vitamin $\mathrm{C}$ đều khác biệt ở mức ý nghĩa ở mức ý nghĩa $P<0,05$. Ở hàm lượng chất khô ban đầu là 15 và $18^{\circ} \mathrm{Bx}$, sau 3 ngày lên men còn lại 7,9 và $7,8^{\circ} \mathrm{Bx}$ và 4 ngày là 6,0 và $6,4^{\circ} \mathrm{Bx}$; hàm lượng cồn tạo thành ở ngày thứ 2 và 3 tương ứng là $0,5-0,7 \% \mathrm{v} / \mathrm{v}$ và $0,9-1,4 \% \mathrm{v} / \mathrm{v} ; \mathrm{pH}$ ở ngày $1,2,3$ giảm từ 3,7 xuống còn 3,1 ở tất cả các hàm lượng khảo sát. Tî lệ hao hụt vitamin $\mathrm{C}$ tăng theo thời gian lên 

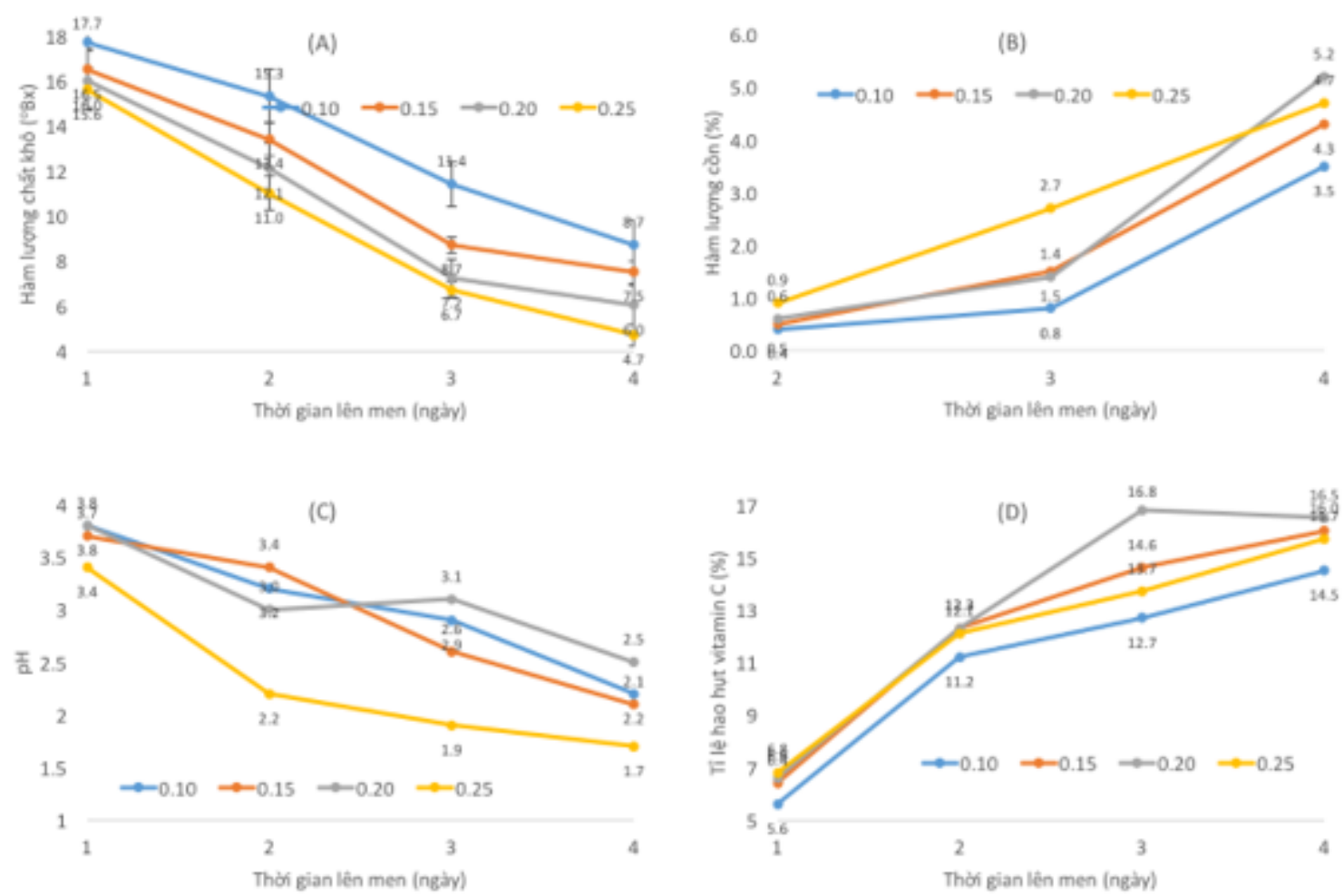

Hình 5. Ảnh hưởng của tỉ lệ men giống đến hàm lượng chất khô $(\mathrm{A})$, hàm lượng cồn $(\mathrm{B})$, pH $(\mathrm{C})$ và tỉ lệ hao hụt hàm lượng vitamin $\mathrm{C}(\mathrm{D})$ theo thời gian lên men.

men, tî̉ lệ này tăng cao ở ngày 1 và ngày 2 có thể vì nồng độ oxy trong môi trường và trong dịch lên men lúc này cao, sự tổn thất vitamin $\mathrm{C}$ do quá trình oxy hoá. Theo tiêu chuẩn hoá lý của sản phẩm (Bui, 2005; Nguyen \& Nguyen, 2007); và từ các số liệu trên cho thấy, ở tất cả các hàm lượng khảo sát, thì $\mathrm{pH}$ và hàm lượng cồn đều đạt tiêu chuẩn của nước quả lên men sau 2 và 3 ngày lên men, riêng hàm lượng chất khô đạt sau 3 và 4 ngày lên men từ hàm lượng chất khô ban đầu là 15 và $18^{\circ} \mathrm{Bx}$. Do đó, hàm lượng chất khô được chọn là 15 và $18^{\circ} \mathrm{Bx}$ thời gian lên men là 3 ngày. Dựa trên kết quả đánh giá cảm quan của hai mẫu này, với số người thích mẫu $18^{\circ} \mathrm{Bx}$ là $42>39_{\alpha_{0,05}}$, do đó hàm lượng chất khô được chọn là $18^{\circ} \mathrm{Bx}$.

\subsection{2. Ảnh hưởng của $\mathrm{pH}$}

pH là yếu tố ảnh hưởng lớn đến sự tạo thành các sản phẩm chính và phụ trong quá trình lên men, đồng thời mức độ thay đổi cơ chất lên men của nấm men cũng bị ảnh hưởng (Hình 4).

pH hoạt động của nấm men Saccharomyces cereviciae 3,5 - 6,0, ở khoảng $\mathrm{pH}$ này nấm men chuyển hoá đường theo con đường EMP sản phẩm pyruvate tạo thành sẽ bị decarboxyl hoá cho ra acetaldehyde, chất này nhận $\mathrm{H}+$ tạo thành rượu etylic. Do đó, theo thời gian lên men hàm lượng đường sẽ giảm, điều này có thể đánh giá thông qua sự giảm hàm lượng chất khô hoà tan, sự giảm $\mathrm{pH}$, đồng thời hàm lượng cồn trong dịch lên men sẽ tăng. Từ biểu đồ các Hình 4 . pH được khảo sát ở 4 điểm $\mathrm{pH} 3,5 ; 4,0 ; 4,5 ; 5,0$ và 5,$5 ;$ tại thời điểm lên men 3 ngày ở pH 4,0 thì hàm lượng chất khô, hàm lượng cồn, $\mathrm{pH}$ đều đạt chỉ tiêu của nước quả lên men (Bui, 2005; Nguyen \& Nguyen, 2007) ở $\mathrm{pH}$ khảo sát 4,0 thu được kết quả tương ứng hàm lượng chất khô $7,2^{\circ} \mathrm{Bx}$; hàm lượng cồn $1,4 \% \mathrm{v} / \mathrm{v}$; pH 3,1. Do đó, pH được chọn cho lên men là 4,0.

\subsection{3. Ảnh hưởng của tỉ lệ men giống}

Mật độ tế bào nấm men trong dịch lên men sẽ ảnh hưởng đến thời gian lên men, tốc độ chuyển hoá cơ chất cũng như hàm lượng các sản phẩm tạo thành (Hình 5). 
Mật độ tế bào nấm men trong dịch lên men càng cao thì quá trình chuyển hoá các chất diễn ra càng nhanh và thời gian lên men được rút ngắn. Điều này được đánh giá thông qua sự giảm hàm lượng chất khô, sự giảm $\mathrm{pH}$ trong dịch lên men và sự tăng hàm lượng cồn. Tuy nhiên, rút ngắn thời gian lên men sẽ làm quá trình chuyển hoá các sản phẩm phụ bị hạn chế, hàm lượng aldehyde tồn tại cao trong sản phẩm, điều này ảnh hưởng đến chất lượng cũng như giá trị cảm quan cho sản phẩm. Tuy nhiên, mật độ tế bào nấm men cũng cần được chọn tỉ lệ phù hợp cho quá trình lên men chuyển hoá các chất để sản phẩm tạo thành đạt các chỉ tiêu hoá lý của sản phẩm. Theo biểu đồ Hình 5 thì tî lệ men giống bổ sung cho sản phẩm đạt chỉ tiêu hoá lý (Bui, 2005; Nguyen \& Nguyen, 2007) ở ngày lên men thứ 3 và tỉ lệ men giống sử dụng là 0,20\%; tương ứng với mật độ men giống sử dụng là 4.107 tế bào $/ \mathrm{mL}$. Qua các khảo sát về sự ảnh hưởng của hàm lượng chất khô, $\mathrm{pH}$, tỉ lệ men giống theo thời gian lên men; các chỉ tiêu đo là hàm lượng chất khô, $\mathrm{pH}$, hàm lượng cồn và hàm lượng vitamin $\mathrm{C}$, nhìn chung đều có sự thay đổi khác biệt theo thời gian khảo sát. Hàm lượng vitamin $\mathrm{C}$ giảm mạnh trong giai đoạn đầu hay ngày lên men thứ 1 và thứ 2 do bị oxy hoá, sau đó giảm nhẹ. Sản phẩm thu được có hàm lượng chất khô $7,2 \pm 0,8^{\circ} \mathrm{Bx}$; hàm lượng cồn $1,4 \% \mathrm{v} / \mathrm{v}$; hàm lượng vitamin $\mathrm{C} \mathrm{581,2mg \% ;} \mathrm{pH} \mathrm{3,1.}$

\section{Kết Luận}

Sản phẩm nước giải khát lên men từ quả sơ ri được chế biến từ dịch quả sau nghiền được xử lý pectinase ở hàm lượng $0,15 \%$ thời gian xử lý là 2 giờ; dịch quả sau xử lý được thanh trùng và điều chỉnh đạt các thông số sau: hàm lượng chất khô $18^{\circ} \mathrm{Bx}, \mathrm{pH} 4,0$; tỉ lệ men giống bổ sung $0,20 \%$; tiến hành lên men trong 3 ngày ở nhiệt độ phòng. Sản phẩm sau lên men được lọc tách bã, đóng chai và thanh trùng ở $75^{\circ} \mathrm{C}$ trong 10 phút. Sản phẩm thu được có hàm lượng chất khô $7,2 \mathrm{Bx}$, hàm lượng cồn $1,4 \%(\mathrm{v} / \mathrm{v})$, hàm lượng vitamin $\mathrm{C}$ là $581,2 \mathrm{mg}$ và $\mathrm{pH}$ là 3,1 .

\section{Tài Liệu Tham Khảo (References)}

Bui, A. (2005). Fermentation technology applied in food technology ( $2^{\text {nd }}$ ed.). Ho Chi Minh City, Vietnam: National University Ho Chi Minh City.

Mathew, B., Silas, D, M., David, E., \& Ugboko, H. (2017). Production of wine from fermentation of Grape ( $\mathrm{Vi}$ tis vinifera) and sweet orange (Citrus seninsis) juice using Saccharomyces cerevisiae isolated from palm wine. International Journal of Current Microbiology and Applied Sciences 6(1), 868-881.

Nguyen, T. D., \& Nguyen, H. T. (2007). Technology for manufacturing and testing ethyl alcohol ( $3^{\text {rd }}$ ed.). Ha Noi, Vietnam: Science and Technics Publishing House.

Oliveira, L., Rufino, M., Moura, F. H., Cavalcanti, F., Alves, R. A., \& Miranda, M. (2010). The influence of processing and long-term storage on the antioxidant metabolism of acerola (Malpighia emarginata) purée. Brazilian Journal of Plant Physiology 23(2), 151-160.

Righetto, M., Netto, A., \& Carraro, F. (2005). Chemical composition and antioxidant activity of juices from mature and immature acerola (Malpighia emarginata DC). Food Science and Technology International 11(4), 315-321.

Saranraj, P., Sivasakthivelan, P., \& Naveen, M. (2017). Fermentation of fruit wine and its quality analysis: A review. Australian Journal of Science and Technology $1(2), 85-97$.

Simopoulos, A. P., \& Gopalan, C. (2003). Plants in human health and nutrition policy. Basel, Switzerland: Karger.

Souza, P. A., Naik, P. A., Rao, S. C., Vyas, S., Palan, A. M., Cornelio, B., Shet, V. B., \& Rao, C. V. (2017). Fermented fruit juice production using unconventional seasonal fruits through batch fermentation. Journal of Microbiology, Biotechnology and Food Sciences 6(6), 1305-1308.

Vendramini, A., \& Trugo, L., (2000). Chemical composition of acerola fruit (Malpighia punicifolia L.) at three stages of maturity. Food Chemistry 71(2000), 195-198. 